\title{
A Soluble Receptor for Advanced Glycation End Product Levels in Patients with Systemic Lupus Erythematosus
}

\author{
Sistemik Lupus Eritematöz Olan Hastalarda İlerlemiş Glikasyon \\ Son Ürün Düzeylerinin Çözünür Reseptörü \\ Nervana BAYOUMY, ${ }^{1}$ Mohamed EL-SHABRAWI,${ }^{2}$ Hesham NADA ${ }^{3}$ \\ ${ }^{1}$ Department of Physiology, King Saud University, Riyadh, Saudi Arabia \\ ${ }^{2}$ Department of Clinical and Chemical Pathology, Suze Canal University, Suze Canal, Egypt \\ ${ }^{3}$ Department of Dermatology and Andrology, Suze Canal University, Suze Canal, Egypt
}

Objectives: In this study, we aimed to evaluate the plasma levels of a soluble receptor for advanced glycation end products (sRAGE) in patients with systemic lupus erythematosus (SLE) and to investigate their relationship with different clinical, laboratory, and therapeutic parameters.

Patients and methods: A total of 120 patients with SLE (111 females, 9 males) and 40 age- and gender-matched healthy controls were included. The plasma sRAGE levels were measured using a commercially available enzyme-linked immunosorbent assay (ELISA). The possible relationship between plasma sRAGE levels with SLE clinical and laboratory characteristics were also assessed. The effectiveness of different therapeutic modalities on plasma sRAGE levels was analyzed.

Results: The SLE patients had significantly lower plasma levels of sRAGE than the healthy controls $(p=0.003)$. The patients with a skin rash or serositis had significantly higher sRAGE levels than those without $(p=0.036$ and $p=0.017$, respectively). The SLE patients who were treated over a longer period of time showed higher levels of sRAGE than those treated for shorter periods $(p=0.000)$. No significant difference in levels was found among the patients treated with corticosteroids and those treated with combined therapy $(p=0.89)$. There was a significant negative correlation between the SRAGE level and the total white blood cell $(\mathrm{WBC})$ count $(r=-0.356 ; p=0.003)$, lymphocytes $(r=0.341 ; p<0.001)$, and neutrophils $(r=-0.289 ; p=0.006)$.

Conclusion: We found significantly decreased plasma sRAGE levels in the SLE patients in our study. This suggests that SRAGE levels may play a role in the pathogenesis of the disease.

Key words: Advanced glycation end product; receptor; systemic lupus erythematosus.
Amaç: Bu çalışmada sistemik lupus eritematöz (SLE) olan hastalarda ileri glikasyon son ürünlerinin çözünür reseptörünün (sRAGE) plazma düzeyleri değerlendirildi ve bu düzeylerin farklı klinik, laboratuvar ve tedavi parametreleri ile olan ilişkisi araştırıldı.

Hastalar ve yöntemler: Çalışmaya toplam 120 SLE hastası (111 kadın, 9 erkek) ve yaş ve cinsiyet eşleştirmeli 40 sağlıklı kontrol alındı. Plazma sRAGE düzeyleri, ticari olarak satılan enzim bağlı immünosorbent test (ELISA) kiti kullanılarak ölçüldü. Plazma sRAGE düzeyleri ve SLE'nin klinik ve laboratuvar özellikleri arasındaki muhtemel ilişki de değerlendirildi. Farklı tedavi yöntemlerinin sRAGE plazma düzeyleri üzerindeki etkinliği incelendi.

Bulgular: Sağlıklı kontrollere kıyasla, SLE hastalarının plazma sRAGE düzeyleri anlamlı düzeyde daha düşüktü $(p=0.003)$. Cilt döküntüsü veya serozit olan hastaların SRAGE düzeyleri, olmayanlara kıyasla anlamlı düzeyde daha yüksekti (sırasıyla $p=0.036$ ve $p=0.017$ ). Daha uzun süre tedavi edilen SLE hastalarının sRAGE düzeyleri, daha kısa süreli tedavi edilenlerden daha yüksekti $(p=0.000)$. Kortikosteroid ile tedavi edilen ve kombine tedavi edilen hastalar arasında düzey açısından anlamlı bir fark yoktu $(p=0.89)$. sRAGE düzeyleri ve total beyaz kan hücre (WBC) sayımı $(r=-0.356 ; p=0.003)$, lenfosit $(r=0.341 ; p<0.001)$ ve nötrofil $(r=0.289 ; p=0.006)$ arasında anlamlı negatif bir ilişki vardı.

Sonuç: Çalışmamızda SLE hastalarında sRAGE plazma düzeylerinin anlamlı derecede azaldığı bulundu. Bu da, sRAGE düzeylerinin hastalığın patogenezinde muhtemel bir rol oynadığını göstermektedir.

Anahtar sözcükler: İleri glikasyon son ürünü; reseptör; sistemik lupus eritematöz.

\footnotetext{
Received: August 8, 2012 Accepted: January 21, 2013

Correspondence: Nervana Bayoumy, M.D. Department of Physiology, King Saud University, 11362 Riyadh, Saudi Arabia.

Tel: 0096614699147 e-mail: nbayoumy@ksu.edu.sa

C2013 Turkish League Against Rheumatism. All rights reserved.
} 
Systemic lupus erythematosus (SLE) is a chronic autoimmune disease characterized by the involvement of multiple organ systems. Its etiology is largely unknown; however, it has been proposed that genetic and environmental factors contribute to breaking tolerance, resulting in the production of a variety of antibodies directed at self-components. ${ }^{[1]}$ These autoantibodies form immune complexes can be deposited in many tissues, particularly the skin and kidneys. ${ }^{[2,3]}$ Currently, research is being conducted to determine what patho-physiological mechanisms are involved in this entire process.

Receptor for advanced glycation end products (RAGE) is a multi-ligand member of the immunoglobulin super-family. It is expressed by most types of immune cells, including macrophages, neutrophils, and $\mathrm{T}$ cells and interacts with several classes of ligands. ${ }^{[4,5]}$ Currently, the known RAGE ligands include the high mobility group box-1 (HMGB1) protein, advanced glycation end products (AGEs), and members of the S100/calgranulin family.

One of the proinflammatory mediators is the HMGB1. It was originally recognized as a DNAbinding protein but has recently been identified as a damage-associated molecular pattern (DAMP) molecule. ${ }^{[6,7]}$ This nuclear protein participates in chromatin architecture and transcriptional regulation, ${ }^{[8]}$ but once released, it induces an inflammatory response. ${ }^{[9,10]}$ Extracellular HMGB1 binds to cell surface receptors, including RAGE, tolllike receptors 2 and 4, and others. Studies have shown that interaction between HMGB1 and RAGE results in the production of type 1 interferon, which plays a key role in the pathogenesis of SLE. ${ }^{[1,12]}$ In addition, tumor necrosis factor-alpha (TNF- $\alpha$ ) and interleukin 6 (IL-6) are produced upon HMGB1 activation of macrophages. ${ }^{[13]}$ It has also been hypothesized that these cytokines also affect some body organs as well as disease flareups. ${ }^{[14,15]}$ In addition, it has also been postulated that RAGE involvement in all pathophysiological processes is reliant on HMGB1. ${ }^{[16]}$ Some studies have reported a relationship between the high serum level of HMGB1 and flare-ups of lupus disease activity. ${ }^{[17,18]}$ All of these observations support the notion that the HMBG1RAGE pathway plays a part in the pathogenesis of SLE.

Another class of ligands is the AGEs. They result from a process in which non-enzymatic glycosylation attaches to circulating compounds such as lipids, proteins, or nucleic acids. This process occurs under the effect of oxidative stress (OS) and hyperglycemia. ${ }^{[19]}$ Accumulations of AGEs have been found in certain diseases, including diabetes mellitus $(\mathrm{DM})$ and Alzheimer's. Since RAGE induction is under the effect of AGEs, the RAGE-AGEs pathway is thought to be incriminated in the pathogenesis of these diseases. ${ }^{[20,21]}$

Receptor for advanced glycation end products is a receptor for a family of about 20 related calciumbinding proteins that are only expressed in vertebrates. These include the S100s, which are cells that alter several intracellular functions. ${ }^{[22]}$ In addition, many types of body cells release S100s during inflammation; therefore, they can be used as a measure of disease activity. ${ }^{[23,24]}$ Furthermore, a significant correlation has been found between high concentrations of serum S100A8/A9 and SLE disease activity, suggesting that it can be used as a reliable test of infection in SLE patients. ${ }^{[25]}$

Soluble RAGE (sRAGE), a truncated form of the receptor, has the same structure but lacks the cytosolic and transmembrane domains. Two general mechanisms are usually responsible for the generation of soluble receptors. These are either derived from the alternative splicing of messenger ribonucleic acid (mRNA) or the cleaved products of the membrane-bound form of metalloproteinase. ${ }^{[26,27]}$ Both sRAGE and complete RAGE have the same ligand-binding specificity. Furthermore, sRAGE may act as a trap for pro-inflammatory ligands such as HMGB1 and inhibit their interaction with the RAGE cell surface. ${ }^{[28]}$ Moreover, sRAGE binds to RAGE, causing the inhibition of its dimerization. This leads to the upregulation of the nuclear factorKappaB (NF- $\mathrm{B}$ ) pathways. Thus, decreased levels of serum sRAGE trigger the stimulation of RAGE signaling and inflammation. In addition, lower levels of serum sRAGE have been detected in several chronic inflammatory diseases, for example multiple sclerosis (MS), primary Sjogren's syndrome, and rheumatoid arthritis (RA). ${ }^{[29,30]}$

To date, only two studies have investigated the serum sRAGE levels in SLE patients, and they reported conflicting results. ${ }^{[31,32]}$ However, experimental animal models have provided encouraging results about the therapeutic role of sRAGE. ${ }^{[33,34]}$ All of these investigations indicate that it could represent a future therapeutic target in chronic inflammatory diseases.

In this study, we investigated the plasma sRAGE levels to determine whether they are associated with disease activity and clinical and laboratory parameters. 


\section{PATIENTS AND METHODS}

Our study was composed of 120 patients with SLE (111 females and 9 males) and 40 age- and gendermatched healthy controls. The SLE patients were selected from those who had received treatment in the Suez Canal University Hospital outpatient clinics from November 2011 to May 2012. All of the patients conformed to the American College of Rheumatology (ACR) classification criteria for the diagnosis of SLE, ${ }^{[35]}$ and active disease was identified using the Systemic Lupus Erythematosus Disease Activity Index (SLEDAI), in which a score of $>4$ represents active disease. ${ }^{[36]}$ This case-control study was approved by the ethics committee of the Suez Canal University and was carried out in accordance with the principles of the Declaration of Helsinki. Informed consent was obtained from all of the participants prior to enrollment in the study.

Demographic and clinical data, including cutaneous manifestations, arthritis, vasculitis, myositis, renal and hematological disorders, along with the patients' history of drug therapy were recorded at the time of blood collection. In addition, tests were conducted to assess the following: blood urea nitrogen level, serum creatinine, proteinuria, and immunological parameters (serum C3, C4, C-reactive protein (CRP), anti-double-stranded deoxyribonucleic acid (anti-dsDNA), and antinuclear antibodies (ANA).

Plasma concentrations of sRAGE levels were measured using a commercially available enzymelinked immunosorbent assay (ELISA) kit (R\&D systems, Inc., Minneapolis, MN, USA) according to the manufacturer's protocol.

The ANA and anti-dsDNA were determined using the AUTOFLUOR ${ }^{\otimes}$ Autoimmuneimmunofluorescence system (DiaSorin, Inc, Stillwater, MN., USA), and these assays were also done according to the manufacturer's instructions. Biochemical assays were carried out using the Roche Hitachi 912 fullyautomated spectrophotometer (Roche Diagnostics $\mathrm{GmbH}$, Mannheim, Germany).

The data was expressed as mean \pm standard deviation (SD), and comparisons between the SLE patients and the controls were analyzed by the Student's t-test, one-way analysis of variance (ANOVA), and Spearman's rank correlation coefficient. The SPSS version 15.0 for Windows software program (SPSS Inc., Chicago, IL, USA) was used to perform all statistical analysis. A two-tailed $p$ value of $<0.05$ was considered to be statistically significant.

\section{RESULTS}

Among the 120 SLE patients, 85 had active disease and 35 had inactive disease. Thirty-five patients were newly diagnosed SLE patients and had not yet received any treatment, 35 were on a monotherapy regimen (corticosteroids), and 50 were on a combination therapy (corticosteroids and immunosuppressors). The demographic characteristics of the patients and controls are shown in Table 1, and the clinical and laboratory characteristics are shown in Table 2. In addition, the plasma sRAGE levels in the different categories of the study groups are shown in Figure 1. The average plasma sRAGE level of all of the SLE patients was significantly lower than that of the controls $(\mathrm{p}=0.003)$, but the healthy controls had significantly higher sRAGE levels than the SLE patients with active and inactive disease $(\mathrm{p}=0.016$ and $\mathrm{p}=0.003$, respectively). However, no significant difference was seen between the active $(922 \pm 58 \mathrm{pg} / \mathrm{ml})$ and inactive $(807 \pm 68 \mathrm{pg} / \mathrm{ml})$ patients with SLE $(\mathrm{p}=0.312)$.

The effect of SLE treatment on the sRAGE levels was similar among the patients who had received treatment and those who had not $(\mathrm{p}=0.85)$, and the levels in both groups were significantly lower than in the healthy controls $(\mathrm{p}=0.005$ and $\mathrm{p}=0.023$, respectively). Furthermore, no significant differences were identified in the sRAGE levels between the SLE patients on the monotherapy regimen and those on combined therapy $(p=0.89)$ as well as between these two groups and the untreated patients.

Concerning the treatment, the plasma sRAGE levels in the SLE patients who had received short-term treatment $(<1$ month) was lower than in the untreated patients $(p=0.020)$. Conversely, the sRAGE levels in patients who had undergone long-term treatment (>1 month) were higher than those who had only been treated for a short period of time $(p<0.001)$, and they were similar to the levels of the control group $(\mathrm{p}=0.31)$.

We also investigated the connections between the plasma sRAGE levels and the different clinical criteria (presence versus absence) and found that the sRAGE levels in the SLE patients with cutaneous manifestations and serositis were significantly higher than for the patients without them $(\mathrm{p}=0.036$ 


\begin{tabular}{|c|c|c|c|c|c|c|}
\hline \multirow[t]{2}{*}{ Features } & \multicolumn{3}{|c|}{$\begin{array}{l}\text { SLE patients } \\
\qquad(\mathrm{n}=120)\end{array}$} & \multicolumn{3}{|c|}{$\begin{array}{l}\text { Controls } \\
(n=40)\end{array}$} \\
\hline & $\mathrm{n}$ & $\%$ & Mean \pm SD & $\mathrm{n}$ & $\%$ & Mean \pm SD \\
\hline Age (years) & & & $33.5 \pm 9.5$ & & & $36.7 \pm 8.5$ \\
\hline Disease duration (months) & & & $33.7 \pm 22$ & & & \\
\hline \multicolumn{7}{|l|}{ Gender } \\
\hline Male & 9 & 7.5 & & 8 & 20 & \\
\hline Female & 111 & 92.5 & & 32 & 80 & \\
\hline Active SLE & 85 & 70.8 & & & & \\
\hline Inactive SLE & 35 & 29.2 & & & & \\
\hline Cutaneous manifestations & 60 & 50 & & & & \\
\hline Arthritis & 66 & 55 & & & & \\
\hline Nephritis & 75 & 63 & & & & \\
\hline Vasculitis & 60 & 50 & & & & \\
\hline Serositis & 14 & 12 & & & & \\
\hline Myositis & 12 & 10 & & & & \\
\hline Hematological disorders & 55 & 46 & & & & \\
\hline Untreated & 35 & 29 & & & & \\
\hline Mono-therapy & 35 & 29 & & & & \\
\hline Combined therapy & 50 & 42 & & & & \\
\hline
\end{tabular}

and $\mathrm{p}=0.017$, respectively). However, no significant associations were observed between sRAGE and the other clinical features.

Additionally, the plasma sRAGE levels in the SLE patients showed significant negative correlations with the total white blood cell (WBC) count ( $\mathrm{r}=$ $0.356, \mathrm{p}=0.003)$, lymphocytes $(\mathrm{r}=-0.341, \mathrm{p}<0.001)$, and neutrophils $(\mathrm{r}=-0.289, \mathrm{p}=0.006)$. As for the glomerular filtration rate (eGFR), it was estimated using the Cockcroft-Gault equation and was not significantly correlated with the sRAGE levels $(\mathrm{p}=0.875)$. The patients with lower eGFRs $\left(<90 \mathrm{ml} / \mathrm{min}\right.$ per $\left.1.73 \mathrm{~m}^{2}\right)$ showed higher sRAGE levels than the patients with normal eGFRs $\left(>90 \mathrm{ml} / \mathrm{min}\right.$ per $\left.1.73 \mathrm{~m}^{2}\right)$, but the difference was not statistically significant $(\mathrm{p}=0.754)$.

\section{DISCUSSION}

Our results showed that the plasma sRAGE levels in the SLE patients in our study were lower than those in the healthy controls. However, disease activity did not exert a significant difference on the sRAGE levels. The decrease in the sRAGE levels could

\begin{tabular}{lcc}
\hline \multicolumn{3}{l}{ Table 2. Laboratory tests for systemic lupus erythematosus patients } \\
\hline Test & Mean \pm SD & Range \\
\hline Anti-dsDNA & Positive in all patients \\
Antinuclear antibodies & Positive in all patients & \\
C3 $(\mathrm{gm} / \mathrm{l})$ & $0.70 \pm 0.35$ & $0.14-1.60$ \\
C4 $(\mathrm{gm} / \mathrm{l})$ & $0.16 \pm 0.06$ & $0.04-1.34$ \\
Urinary Protein $(\mathrm{gm} / \mathrm{day})$ & $1.26 \pm 0.95$ & $0.10-6.60$ \\
Creatinine $(\mathrm{mg} / \mathrm{dl})$ & $1.79 \pm 0.75$ & $0.67-5.80$ \\
Urea $(\mathrm{mg} / \mathrm{dl})$ & $60 \pm 25$ & $38-220$ \\
C-reactive protein $(\mathrm{mg} / \mathrm{L})$ & $18.44 \pm 9.75$ & $0.55-122.0$ \\
White blood cells $\left(10^{3} / \mu \mathrm{l}\right)$ & $7.98 \pm 5.64$ & $0.90-27.00$ \\
Platelets $\left(10^{3} / \mu \mathrm{l}\right)$ & $187 \pm 80$ & $15-680$ \\
Hemoglobin $(\mathrm{gm} / \mathrm{dl})$ & $11.6 \pm 2.9$ & $4.1-14.80$ \\
Lymphocytes $\left(10^{3} / \mu \mathrm{l}\right)$ & $1.45 \pm 0.85$ & $0.20-6.10$ \\
Neutrophils $\left(10^{3} / \mu \mathrm{l}\right)$ & $6.12 \pm 3.32$ & $0.40-25.10$ \\
\hline Anti-dsDNA: Anti-double-stranded deoxyribonucleic acid. & \\
\hline
\end{tabular}




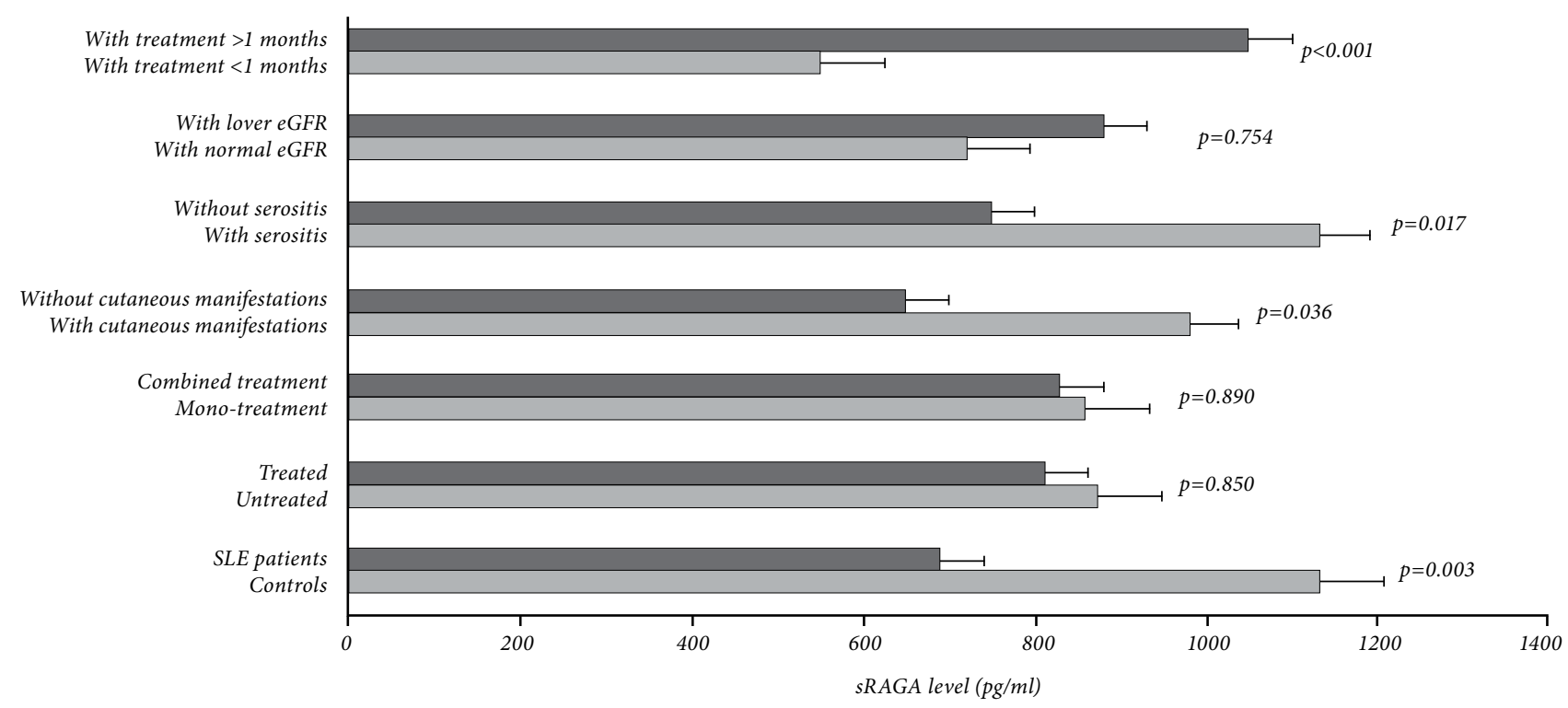

Figure 1. Plasma levels of soluble receptor for advanced glycation end products in the control group and systemic lupus erythematosus (SLE) patients. The histogram and error bars show the mean level and standard deviation. eGFR: Estimated glomerular filtration rate.

be explained by the consumption of this soluble receptor. It has long been thought that a clearance pathway of these sRAGE-ligand complexes exists through the spleen and/or liver. ${ }^{[37]}$ Studies have shown that the HMGB1 plasma level, one of the main RAGE ligands, is increased in the circulation of SLE, leading to the binding and consumption of sRAGE during the inflammatory process. ${ }^{[18,38]}$ Another possible regulatory route of the sRAGE level is through alternative splicing and proteinases. Zong et al. ${ }^{[39]}$ recently proposed that sRAGE might not only function as a 'decoy' to exert its inhibitory effects on RAGE but also act in a more direct way by binding to the cell surface of RAGE to block the formation of homodimers. Hence, the decreased levels of sRAGE could contribute to enhanced RAGE-mediated pro-inflammatory signaling, thus supporting the possibility of the essential role of RAGE in SLE pathology.

The results of this study are in agreement with a similar recent study on 105 SLE Chinese patients by $\mathrm{Ma}$ et $\mathrm{al},{ }^{[32]}$ but they differ from a report from the Netherlands which showed that blood sRAGE levels in patients with SLE were higher than those found in healthy controls. Furthermore, when compared with quiescent SLE, the blood sRAGE levels were significantly increased during active disease in the Dutch study. ${ }^{[31]}$ This difference might be attributed to the fact that the latter study only included 10 SLE patients (9 Caucasians and 1 Asian). Also, the usage of different medication regimes could have been an influential factor.

In our study, we evaluated the association between sRAGE levels and the main clinical SLE characteristics, and neither patient age nor disease duration showed any correlation with receptor levels. However, the SLE patients with cutaneous manifestations and serositis had higher sRAGE levels compared with those without them $(p=0.035$ and $p=0.017$, respectively). We also determined that the patients with other manifestations, such as arthritis, myositis, vasculitis, hematological disorders, and renal disorders, had similar sRAGE levels with those who did not.

The effect of impaired renal function on sRAGE levels was identified in some studies in which the patients had increased levels. ${ }^{[40]}$ In addition, in a study by Tan et al., ${ }^{[41]}$ serum sRAGE was found to be associated with the severity of nephropathy in patients with type 2 diabetes. In the present study, the plasma sRAGE levels were higher in the patients with lower eGFRs than in those with normal eGFRs, but the difference was not statistically significant. Additionally, the prevalence of SLE clinical manifestations differs in different populations; ${ }^{[42]}$ thus, more research is needed on this topic.

Some studies have shown that sRAGE levels are affected by various types of therapy, ${ }^{[43]}$ and an association between methotrexate and significantly higher sRAGE levels in the synovial fluid of RA 
patients has also been reported. However, these higher levels were absent in the study by Pullerits et al. ${ }^{[44]}$ in which the patients were treated with non disease-modifying/anti-rheumatic agents. Our results showed that there was no statistically significant difference between the plasma sRAGE levels in the treated and untreated SLE patients, $(p=0.85)$ yet the SLE patients on short-term treatment showed a rapid and significant decrease in their plasma sRAGE levels. We also found that the SLE patients who had been treatment for less than one month had lower plasma sRAGE levels than even the untreated patients. Conversely, the patients treated for longer periods had higher sRAGE levels than those on a short therapeutic regimen. These results are an agreement with the study by $\mathrm{Ma}$ et al. ${ }^{[32]}$ This suggests that immediate and long-term therapeutic treatments have different effects on the plasma sRAGE levels in patients with SLE, which suggests that sRAGE may play a different role in the initial and progressive stages of the disease. However, the use of antilupus therapy could be involved in the triggering of a compensating mechanism that alters sRAGE production and/or regulation.

In addition, RAGE has been implicated in leucocyte migration. Chavakis et al. ${ }^{[45]}$ reported that cell-bound RAGE functioned as a counter-receptor for leucocyte integrin Mac-1 and was directly involved in leucocyte recruitment. Hence, sRAGE has been proposed to function as a potential inhibitor of leucocyte recruitment. Our results showed significant negative correlations between sRAGE levels and the total WBC count, lymphocytes, and neutrophils. This further highlights that sRAGE is associated with the inflammatory process of SLE.

This is the third study to examine sRAGE levels in SLE patients and the first involving an Arab population. Our study benefited from having the largest number of cases along with age- and gendermatched controls. However, the controls were volunteers, and it is possible that some of them might have had underlying diseases which could have affected our results.

The results of this study emphasize the possible involvement of the RAGE pathway in the pathogenesis of SLE, which could lead to it having a potential therapeutic role. Further studies are required to investigate the changes of sRAGE in disease progression and the possibility of preventing or delay in the SLE complication.

\section{Declaration of conflicting interests}

The authors declared no conflicts of interest with respect to the authorship and/or publication of this article.

\section{Funding}

The authors received no financial support for the research and/or authorship of this article.

\section{REFERENCES}

1. Shirai T, Hirose S. Molecular pathogenesis of SLE. Springer Semin Immunopathol 2006;28:79-82.

2. Abdulahad DA, Westra J, Limburg PC, Kallenberg CG, Bijl M. HMGB1 in systemic lupus Erythematosus: Its role in cutaneous lesions development. Autoimmun Rev 2010;9:661-5. doi: 10.1016/j.autrev.2010.05.015.

3. Tokumoto M, Fukuda K, Shinozaki M, Kashiwagi M, Katafuchi R, Yoshida T, et al. Acute interstitial nephritis with immune complex deposition and MHC class II antigen presentation along the tubular basement membrane. Nephrol Dial Transplant 1999;14:2210-5.

4. Schmidt AM, Yan SD, Yan SF, Stern DM. The biology of the receptor for advanced glycation end products and its ligands. Biochim Biophys Acta 2000;1498:99-111.

5. Schmidt AM, Yan SD, Yan SF, Stern DM. The multiligand receptor RAGE as a progression factor amplifying immune and inflammatory responses. J Clin Invest 2001;108:949-55.

6. Bianchi ME. DAMPs, PAMPs and alarmins: all we need to know about danger. J Leukoc Biol 2007;81:1-5.

7. Harris HE, Raucci A. Alarmin(g) news about danger: workshop on innate danger signals and HMGB1. EMBO Rep 2006;7:774-8.

8. Bianchi ME, Agresti A. HMG proteins: dynamic players in gene regulation and differentiation. Curr Opin Genet Dev 2005;15:496-506.

9. Fiuza C, Bustin M, Talwar S, Tropea M, Gerstenberger E, Shelhamer JH, et al. Inflammation-promoting activity of HMGB1 on human microvascular endothelial cells. Blood 2003;101:2652-60.

10. Hreggvidsdottir HS, Ostberg T, Wähämaa H, Schierbeck $\mathrm{H}$, Aveberger AC, Klevenvall L, et al. The alarmin HMGB1 acts in synergy with endogenous and exogenous danger signals to promote inflammation. J Leukoc Biol 2009;86:655-62. doi: 10.1189/jlb.0908548.

11. Niewold TB, Hua J, Lehman TJ, Harley JB, Crow MK. High serum IFN-alpha activity is a heritable risk factor for systemic lupus erythematosus. Genes Immun 2007;8:492-502.

12. Tian J, Avalos AM, Mao SY, Chen B, Senthil K, Wu H, et al. Toll-like receptor 9-dependent activation by DNAcontaining immune complexes is mediated by HMGB1 and RAGE. Nat Immunol 2007;8:487-96. 
13. Andersson U, Wang $\mathrm{H}$, Palmblad K, Aveberger AC, Bloom O, Erlandsson-Harris $\mathrm{H}$, et al. High mobility group 1 protein (HMG-1) stimulates proinflammatory cytokine synthesis in human monocytes. J Exp Med 2000;192:565-70.

14. Tackey E, Lipsky PE, Illei GG. Rationale for interleukin-6 blockade in systemic lupus erythematosus. Lupus 2004;13:339-43.

15. Aringer M, Smolen JS. The role of tumor necrosis factoralpha in systemic lupus erythematosus. Arthritis Res Ther 2008;10:202. doi: 10.1186/ar2341.

16. Bianchi ME, Manfredi AA. High-mobility group box 1 (HMGB1) protein at the crossroads between innate and adaptive immunity. Immunol Rev 2007;220:35-46.

17. Li J, Xie H, Wen T, Liu H, Zhu W, Chen X. Expression of high mobility group box chromosomal protein 1 and its modulating effects on downstream cytokines in systemic lupus erythematosus. J Rheumatol 2010;37:766-75. doi: 10.3899/jrheum.090663.

18. Ma CY, Jiao YL, Zhang J, Yang QR, Zhang ZF, Shen YJ, et al. Elevated plasma level of HMGB1 is associated with disease activity and combined alterations with IFN- $\alpha$ and TNF- $\alpha$ in systemic lupus erythematosus. Rheumatol Int 2012;32:395-402. doi: 10.1007/s00296010-1636-6.

19. Mohamed AK, Bierhaus A, Schiekofer S, Tritschler H, Ziegler R, Nawroth PP. The role of oxidative stress and NF-kappaB activation in late diabetic complications. Biofactors 1999;10:157-67.

20. Huebschmann AG, Regensteiner JG, Vlassara H, Reusch JE. Diabetes and advanced glycoxidation end products. Diabetes Care 2006;29:1420-32.

21. Srikanth V, Maczurek A, Phan T, Steele M, Westcott B, Juskiw D, et al. Advanced glycation endproducts and their receptor RAGE in Alzheimer's disease. Neurobiol Aging 2011;32:763-77. doi: 10.1016/j. neurobiolaging.2009.04.016.

22. Donato R. S100: a multigenic family of calcium-modulated proteins of the EF-hand type with intracellular and extracellular functional roles. Int J Biochem Cell Biol 2001;33:637-68.

23. Frosch M, Strey A, Vogl T, Wulffraat NM, Kuis W, Sunderkötter C, et al. Myeloid-related proteins 8 and 14 are specifically secreted during interaction of phagocytes and activated endothelium and are useful markers for monitoring disease activity in pauciarticularonset juvenile rheumatoid arthritis. Arthritis Rheum 2000;43:628-37.

24. Foell D, Roth J. Proinflammatory S100 proteins in arthritis and autoimmune disease. Arthritis Rheum 2004;50:3762-71.

25. Soyfoo MS, Roth J, Vogl T, Pochet R, Decaux G. Phagocyte-specific S100A8/A9 protein levels during disease exacerbations and infections in systemic lupus erythematosus. J Rheumatol 2009;36:2190-4. doi: 10.3899/ jrheum.081302.
26. Hanford LE, Enghild JJ, Valnickova Z, Petersen SV, Schaefer LM, Schaefer TM, et al. Purification and characterization of mouse soluble receptor for advanced glycation end products (sRAGE). J Biol Chem 2004;279:50019-24.

27. Yonekura H, Yamamoto Y, Sakurai S, Petrova RG, Abedin MJ, Li H, et al. Novel splice variants of the receptor for advanced glycation end-products expressed in human vascular endothelial cells and pericytes, and their putative roles in diabetes-induced vascular injury. Biochem J 2003;370:1097-109.

28. Maillard-Lefebvre H, Boulanger E, Daroux M, Gaxatte C, Hudson BI, Lambert M. Soluble receptor for advanced glycation end products: a new biomarker in diagnosis and prognosis of chronic inflammatory diseases. Rheumatology (Oxford) 2009;48:1190-6. doi: 10.1093/ rheumatology/kep199.

29. Sternberg Z, Weinstock-Guttman B, Hojnacki D, Zamboni P, Zivadinov R, Chadha K, et al. Soluble receptor for advanced glycation end products in multiple sclerosis: a potential marker of disease severity. Mult Scler 2008;14:759-63. doi: $10.1177 / 1352458507088105$.

30. Stewart C, Cha S, Caudle RM, Berg K, Katz J. Decreased levels of soluble receptor for advanced glycation end products in patients with primary Sjögren's syndrome. Rheumatol Int 2008;28:771-6. doi: 10.1007/s00296-0080529-4.

31. Nienhuis HL, de Leeuw K, Bijzet J, Smit A, Schalkwijk CG, Graaff R, et al. Skin autofluorescence is increased in systemic lupus erythematosus but is not reflected by elevated plasma levels of advanced glycation endproducts. Rheumatology (Oxford) 2008;47:1554-8. doi: 10.1093/ rheumatology/ken302.

32. Ma CY, Ma JL, Jiao YL, Li JF, Wang LC, Yang QR, et al. The plasma level of soluble receptor for advanced glycation end products is decreased in patients with systemic lupus erythematosus. Scand J Immunol 2012;75:614-22. doi: 10.1111/j.1365-3083.2012.02691.x.

33. Hofmann MA, Drury S, Hudson BI, Gleason MR, Qu W, Lu Y, et al. RAGE and arthritis: the G82S polymorphism amplifies the inflammatory response. Genes Immun 2002;3:123-35.

34. Abdulahad DA, Westra J, Bijzet J, Limburg PC, Kallenberg CG, Bijl M. High mobility group box 1 (HMGB1) and anti-HMGB1 antibodies and their relation to disease characteristics in systemic lupus erythematosus. Arthritis Res Ther 2011 ;13:R71. doi: 10.1186/ar3332.

35. Hochberg MC. Updating the American College of Rheumatology revised criteria for the classification of systemic lupus erythematosus. Arthritis Rheum 1997;40:1725.

36. Bombardier C, Gladman DD, Urowitz MB, Caron $\mathrm{D}$, Chang $\mathrm{CH}$. Derivation of the SLEDAI. A disease activity index for lupus patients. The Committee on Prognosis Studies in SLE. Arthritis Rheum 1992;35:630-40. 
37. Renard C, Chappey O, Wautier MP, Nagashima M, Lundh E, Morser J, et al. Recombinant advanced glycation end product receptor pharmacokinetics in normal and diabetic rats. Mol Pharmacol 1997;52:54-62.

38. Li J, Xie H, Wen T, Liu H, Zhu W, Chen X. Expression of high mobility group box chromosomal protein 1 and its modulating effects on downstream cytokines in systemic lupus erythematosus. J Rheumatol 2010;37:766-75. doi: 10.3899/jrheum.090663.

39. Zong H, Madden A, Ward M, Mooney MH, Elliott CT, Stitt AW. Homodimerization is essential for the receptor for advanced glycation end products (RAGE)-mediated signal transduction. J Biol Chem 2010;285:23137-46. doi: 10.1074/jbc.M110.133827.

40. Kalousová M, Hodková M, Kazderová M, Fialová J, Tesar V, Dusilová-Sulková S, et al. Soluble receptor for advanced glycation end products in patients with decreased renal function. Am J Kidney Dis 2006;47:406-11.
41. Tan KC, Shiu SW, Chow WS, Leng L, Bucala R, Betteridge DJ. Association between serum levels of soluble receptor for advanced glycation end products and circulating advanced glycation end products in type 2 diabetes. Diabetologia 2006;49:2756-62.

42. Bastug F, Poyrazoglu H, Gunduz Z, Tulpar S, Dusunsel R. Juvenile lupus erythematosus: fourteen years of experience. Turk J Rheumatol 2011;26:308-15.

43. Santilli F, Bucciarelli L, Noto D, Cefalù AB, Davì V, Ferrante E, et al. Decreased plasma soluble RAGE in patients with hypercholesterolemia: effects of statins. Free Radic Biol Med 2007;43:1255-62.

44. Pullerits R, Bokarewa M, Dahlberg L, Tarkowski A. Decreased levels of soluble receptor for advanced glycation end products in patients with rheumatoid arthritis indicating deficient inflammatory control. Arthritis Res Ther 2005;7:R817-24.

45. Chavakis T, Bierhaus A, Al-Fakhri N, Schneider D, Witte S, Linn $\mathrm{T}$, et al. The pattern recognition receptor (RAGE) is a counterreceptor for leukocyte integrins: a novel pathway for inflammatory cell recruitment. J Exp Med 2003;198:1507-15. 